\title{
Strategi Guru Dalam Mengatasi Kejenuhan Belajar Daring Pada Siswa SMAN 4 Semarang Selama Masa Pandemi
}

\section{Teacger's Strategy In Overcoming Online Learning Boredom In SMAN 4 Semarang Students During Pandemic}

\author{
Maria Yuliana Wangge ${ }^{\left(1^{*}\right)}$, Agung Pribadi Santoso(2), Vivit Kartika(3) \& Umi Farida \\ Febriani(4) \\ Fakultas Psikologi, Universitas Semarang, Indonesia
}

Disubmit: 05 Juli 2021; Diproses: 05 Juli 2021; Diaccept: 26 Juli 2021; Dipublish: 02 Agustus 2021

*Corresponding author: E-mail: mariayuliana@usm.ac.id

\begin{abstract}
Abstrak
Penelitian ini bertujuan untuk mengetahui efektivitas pelatihan tentang strategi guru dalam mengatasi kejenuhan belajar siswa selama pembelajaran Daring. Pandemi covid 19 memberikan pengaruh terhadap semua aspek kehidupan salah satunya adalah pendidikan. Untuk mencegah meningkatnya kasus covid maka kegiatan pembelajaran harus dilakukan dalam jaringan (Daring). Dalam proses pelaksanaanya berbagai kendala dihadapi salah satunya adalah kejenuhan siswa dalam mengikuti pembelajaran Daring. Kejenuhan belajar yang dialami oleh siswa berpengaruh pada kelancaran proses belajar mengajar DARING selama masa pandemi. Oleh karena itu guru dituntut untuk memberikan strategi-strategi untuk mengurangi tingkat kejenuhan belajar siswa selama masa pandemi. Subjek dalam penelitian ini adalah guru SMAN 4 Semarang yang berjumlah 20 orang. Metode pelaksanaan adalah dengan memberikan pelatihan kepada guru tentang strategi yang perlu dilakukan untuk mengurangi kejenuhan belajar siswa. Hasil analisis dengan Paired Sample T-Tes menunjukkan adanya peningkatan pemahaman guru dengan skor perbedaan mean pretest 16,95 dan posttest 38,90 dengan T Test untuk ekuitas sebesar 0,018. Hasil analisis pretest dan posttest tersebut menunjukkan adanya peningkatan pemahaman guru terkait materi tentang strategi guru dalam mengatasi kejenuhan belajar Daring selama masa pandemi.
\end{abstract}

Kata Kunci: Kejenuhan Belajar; Strategi

\begin{abstract}
This study aims to determine the effectiveness of training related to teacher strategies in overcoming student learning boredom during online learning. The Covid 19 pandemic has an impact on all aspects of life, one of which is education. To prevent the increase in covid cases, learning activities must be carried out online (online). In the implementation process, various obstacles are faced, one of which is student saturation in taking online learning. The saturation of learning experienced by students has an effect on the smooth teaching and learning process of DARING during the pandemic. Therefore, teachers are required to provide strategies to reduce the level of student learning boredom during the pandemic. The subjects in this study were 20 teachers of SMAN 4 Semarang. The method of implementation is to provide training to teachers on strategies that need to be done to reduce student learning boredom. The results of the analysis with the Paired Sample T-Test showed an increase in teacher understanding with the mean difference score between pretest 16.95 and posttest 38.90 with a T test for equity of 0.018 . From results of the pretest and posttest analyzes showed an increase in understanding of the material related to teacher strategies in overcoming online learning boredom during the pandemic.
\end{abstract}

Keywords: Boredom Of Learning; Strategies

DOI: https://doi.org/10.51849/j-p3k.v2i2.109

Rekomendasi mensitasi :

Wangge, M.Y. Santoso, A.P. Kartika, V. \& Febriani, U.F. (2021), Strategi Guru dalam Mengatasi Kejenuhan Belajar Siswa SMAN 4 Semarang Selama Masa Pandemi. Jurnal Penelitian Pendidikan, Psikologi dan Kesehatan (J-P3K), 2 (2): 135-141. 


\section{PENDAHULUAN}

Wabah corona virus disease 2019 (Covid-19) telah melanda hampir semua negara di dunia, hal ini memberikan dampak bagi segala aspek kehidupan salah satunya pendidikan. Seluruh jenjang Pendidikan mulai dari pendidikan anak usia dini, pendidikan dasar / Madrasah Ibtidaiyah hingga perguruan tinggi (universitas) baik yang berada dibawah Kementerian Pendidikan dan Kebudayaan RI maupun yang berada dibawah Kementerian Agama RI semuanya harus mengikuti kegiatan pembelajaran dari rumah (Purwanto et al., 2020)

Untuk menekan laju perkembangan virus Covid-19 pemerintah telah mengeluarkan sejumlah kebijakan seperti larangan berkerumun di tempat umum, pembatasan sosial (social distancing) dan menjaga jarak fisik (physical distancing), memakai masker serta mencuci tangan (Fikri et al., 2021). Berdasarkan Surat Edaran Nomor 4 Tahun 2020 tentang Pelaksanaan Kebijakan Pendidikan dalam masa darurat penyebaran virus, Mendikbud menyampaikan bahwa proses pembelajaran harus dilakukan melalui online/daring dan tidak diijinkan untuk melakukan pembelajaran tatap muka.

Menurut Riany (dalam Putria et al., 2020) pada dasarnya kegiatan pembelajaran online/daring lebih berpusat pada siswa, dimana siswa harus berperan aktif dan teliti dalam menerima dan memproses informasi yang diperoleh. Meskipun pembelajaran daring saat ini menjadi solusi di masa pandemi COVID-19, namun memiliki kendala dan kekurangan dalam pelaksanaanya. Selain itu banyak bapak ibu guru yang masih belum memahami penggunaan fasilitas daring dalam proses pembelajaran. Guru lebih banyak memberikan tugas dan siswa dipaksa untuk lebih mandiri dalam belajar, hal ini menyebabkan siswa merasa tertekan (Nurkholis Nurkholis, 2020).

Pada pembelajaran online/ Daring, siswa menjadi lebih pasif, mereka kurang mampu menyampaikan aspirasi dan pemikirannya yang menimbulkan kegiatan pembelajaran menjadi kurang menyenangkan menjenuhkan (Rimbarizki, 2017) Menurut Agustin (dalam Muna, 2013) kejenuhan belajar adalah keadaan emosional yang dialami oleh siswa dimana ada perasaan bosan dan lelah secara fisik maupun psikis karena meningkatnya tuntutan akademik yang mengakibatkan siswa enggan mengikuti kegiatan pembelajaran serta menurunya motivasi belajar.

Kejenuhan belajar yang dialami peserta didik dapat menyebabkan rendahnya prestasi belajar karena ketidakmampuan dalam berpikir dimana otak tidak mampu memproses informasi yang diperoleh siswa selama kegiatan belajar. Selain itu kejenuhan belajar juga menyebabkan siswa menjadi kurang efektif dalam mengikuti kegiatan belajar (Arirahmanto, 2016).

Adapun aspek-aspek kejenuhan belajar menurut Scaufely dan Enzmann dalam (Magrur et al., 2020) yakni kelelahan secara emosi, kelelahan fisik, kelelahan kognitif dan menurunnya motivasi. Menurut (MuhibbinSyah, 2014) kejenuhan belajar diakibatkan berbagai faktor yakni kecemasan siswa terhadap standar atau patokan yang diberikan, karena siswa berada pada situasi yang kompetitif dan karena perbedaan 
pemahaman konsep tentang kinerja akademik siswa.

(Pawicara \& Conilie, 2020) menjelaskan bahwa kejenuhan belajar daring selama masa pandemik disebabkan oleh beberapa faktor yakni metode pembelajaran yang monoton, intonasi selama proses pembelajaran kurang bervariasi, tidak dapat berinteraksi langsung dengan teman dan guru serta sistem pembelajaran yang tidak efektif menyebabkan materi yang disampaiakan oleh pendidik kurang dipahami.

Kejenuhan belajar selama masa pandemi juga dialami oleh siswa-siswi di SMAN 4 Semarang. Berdasarkan hasil wawancara dengan guru BK dan beberapa guru mata pelajaran di SMAN 4 Semarang menyatakan adanya penurunan motivasi belajar DARING pada siswa hal ini ditunjukkan dengan absensi yang tinggi, rendahnya minat dalam mengikuti pembelajaran online, kurang antusias mengerjakan tugas-tugas sekolah dan bolos sekolah.

Menurut (Ratna et al, 2008) kejenuhan belajar tidak hanya disebabkan oleh faktor internal siswa melainkan juga faktor eksternal seperti metode dalam pembelajaran. Dijelaskan bahwa cara mengajar yang terlalu monoton dapat meningkatkan rasa jenuh siswa dalam proses belajar mengajar.

Pada masa pandemi covid 19 peran guru dalam pembelajaran sangat dibutuhkan oleh setiap siswa. Guru harus mempunyai kreativitas, inovasi serta motivasi dalam melaksanakan pembelajaran Daring. Oleh karena itu untuk meningkatkan kompetensi guru agar dapat membantu mengurangi kejenuhan belajar siswa khususnya siswa di SMAN 4 Semarang maka guru perlu diberikan pemahaman terkait strategi dalam sistem pembelajaran supaya siswa lebih bersemangat dalam proses pembelajaran ( et al, 2020).

Nasution (2017) menjelaskan bahwa strategi pembelajaran merupakan metode kegiatan yang dirancang dan digunakan oleh guru secara kontekstual sesuai dengan karakteristik peserta didik, kondisi sekolah, lingkungan sekitar dan tujuan pembelajaran yang telah dirumuskan. Lebih lanjut dijelaskan bahwa strategi pembelajaran terdiri dari teknik, metode, dan prosedur yang akan menjamin bahwa peserta didik dapat mencapai tujuan pembelajaran.

Aspek-aspek dalam strategi pembelajaran menurut Gulo (2008) yakni adanya tujuan pembelajaran, pendidik, peserta didik, materi pembelajaran, metode yang akan diterapkan, media pembelajaran serta administrasi dan finansial sebagai penentu berjalannya pembelajaran. Strategi pembelajaran yang menarik disertai dengan dukungan sistem akan membantu siswa untuk lebih termotivasi dalam melaksanakan kegiatan pembelajaran Daring selama masa pandemi. Oleh karena itu guru perlu diberikan pelatihan untuk meningkatkan kapasitas dalam proses belajar mengajar.

Penelitian dari (Lisman et al., 2020) yang dilakukan pada siswa di MTs AlMaarif Banyorang menyatakan bahwa salah satu faktor penting yang memengaruhi kejenuhan belajar siswa adalah metode atau strategi pembelajaran yang diberikan guru. strategi pembelajaran yang monoton atau tidak bervariasi dapat menyebabkan rasa bosan dan jenuh pada peserta didik ketika mengikuti kegiatan 
belajar mengajar. Pelatihan yang diberikan kepada guru akan meningkatan pemahaman guru terkait strategi pembelajaran daring selama masa pandemi.

\section{METODE PENELITIAN}

Metode yang digunakan dalam penelitian ini adalah metode eksperimen dengan desain pretest dan posttes satu kelompok. Variabel dalam penelitian ini adalah Kejenuhan Belajar dan strategi pembelajaran.

Kejenuhan Belajar adalah emosi negative yang dirasakan oleh siswa dimana siswa merasa lelah dan bosan untuk mengikuti kegiatan pembelajaran.

Strategi pembelajaran adalah pendekatan secara menyeluruh dalam mengelola kegiatan belajar untuk menyampaikan materi pembelajaran agar lebih efektif dan efisien.

Subjek dalam penelitian ini adalah guru yang mengajar di SMAN 4 Semarang yang berjumlah 20 orang. Pretes dan Posttes diberikan sebelum dan sesudah kegiatan pelatihan. Terdapat delapan pertanyaan terkait pemahaman guru tentang kejenuhan belajar. Teknik pengolahan data dilakukan menggunakan uji beda (T-Test).

\section{HASIL DAN PEMBAHASAN}

Berdasarkan hasil pretest dan posttest terkait pemahaman guru tentang strategi mengatasi kejenuhan belajar pada siswa diketahui ada perbedaan pemahaman guru sebelum dan sesudah diberikan pelatihan.
Tabel 1. Hasil Pretest dan Posttest

\begin{tabular}{lll}
\hline Kelompok & $\mathrm{N}$ & Mean \\
\hline Kejenuhan & 20 & 16,95 \\
& 20 & 38,90 \\
\hline Sumber Tabel: (Hasil Analisis SPSS)
\end{tabular}

Hasil analisis dengan Paired Sample T-Tes menunjukkan adanya peningkatan pemahaman guru dengan skor perbedaan mean pretest 16,95 dan posttest 38,90 dengan T Test untuk ekuitas sebesar 0,018.

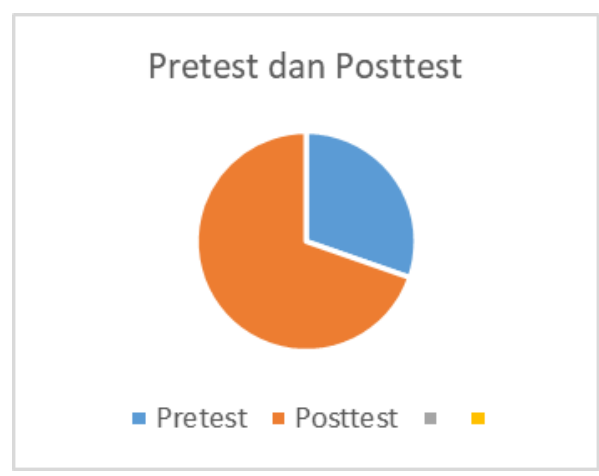

Gambar 1. Diagram hasil Pretest Posttest

Dari diagram diatas dapat dilihat dengan jelas perbedaan hasil pretest dan posttes. Dimana sebelum diberikan materi subjek belum memiliki pemahaman tentang strategi mengatasi kejenuhan belajar pada siswa namun setelah diberikan materi subjek terlihat sudah mampu memahami materi terkait mengatasi kejenuhan belajar pada siswa.

Kegiatan pelatihan berlangsung selama 90 menit, dimana pada 45 pertama dilakukan pemamparan materi dan 45 menit selanjutnya dilanjutkan dengan diskusi dan tanya jawab. Sebelum materi disampaikan subjek diminta untuk mengisi soal pretest.

Terdapat 8 soal untuk pretest. Materi berisi pemahaman tentang pembelajaran daring, kelebihan dan kekurangan pembelajaran daring, dampak pembelajaran daring bagi siswa, 
pemahaman tentang kejenuhan belajar, karakteristik siswa yang mengalami kejenuhan belajar, faktor-faktor yang memengaruhi kejenuhan belajar serta strategi guru untuk mengatasi kejenuhan belajar siswa.

Setelah pemberian materi dan proses diskusi selesai pada sesi terakhir subjek diminta untuk mengisi pertanyaan posttes. pertanyaan yang sama diberikan kembali kepada subjek pada saat pengisian posttes. Adanya perbedaan hasil yang signifikan antara pretes dan posttes menunjukkan bahwa guru sudah memahami materi pelatihan yang diberikan terkait strategi apa saja yang dapat diberikan pada siswa untuk mengurangi kejenuhan belajar

Menurut Pekrun dalam (Tze et al., 2016) Kejenuhan belajar merupakan emosi negatif yang disebabkan oleh rasa bosan dalam belajar sehingga berkurangnya minat dan motivasi serta menurunnya prestasi belajar. Berdasarkan penelitian dari (Handayani, 2020) Kejenuhan belajar yang dialami oleh siswa selama masa pandemi disebabkan oleh berbagai faktor yakni metode pembelajaran, kurangnya interaksi antara guru dan murid, lingkungan belajar yang kurang kondusif, penyampaian materi ajar yang kurang tepat yang diakibatkan jaringan internet yang buruk, banyaknya tugas sekolah yang diberikan.

(Hui \& Lin, 2010) menjelaskan kejenuhan belajar dapat menyebabkan beberapa hal yakni menurunnya motivasi belajar, hilangnya minat belajar, mengalami stress dengan tugas-tugas sekolah dan menarik diri dari sekolah. Sama halnya dengan penjelasan Hui dan Lin, (Daschmann et al., 2011) juga menjelaskan bahwa siswa yang mengalami kejenuhan belajar yang tinggi akan menyebabkan berbagai permasalahan seperti permasalahan akademis termasuk nilai yang rendah, absensi dan putus sekolah, masalah perilaku, stress dan gangguan lainnya.

Lebih lanjut Hui dan Lin (Daschmann et al., 2011) menjelaskan bahwa guru harus mendapatkan pelatihan untuk memeroleh pemahaman baru terkait dengan karakteristik kejenuhan yang dialami siswa sehingga mampu mengatasi permasalahan yang dihadapi siswa. Witt, Wheeless dan Allen dalam (Al-Shara, 2015) mengatakan bahwa guru yang dapat memberikan strategi pembelajaran yang menarik dan menciptakan situasi belajar yang kondusif akan meningkatan interaksi dan semangat belajar bagi siswa.

Menurut Hakim dalam (Handayani, 2020) metode yang dapat dilakukan oleh guru untuk mengurangi kejenuhan belajar siswa adalah dengan memberikan metode belajar yang variatif selain itu siswa dapat menata ulang ruang belajar, menciptakan suasana baru, melakukan rekreasi dan pada saat proses belajar dimulai siswa diharapkan untuk tidak stress.

(MuhibbinSyah, 2014), Talkudung dan Milsidayu dalam (Rinawati \& Darisman, 2020) menjelaskan bahwa siswa juga dapat melakukan berbagai strategi untuk mengatasi kejenuhan belajar di rumah seperti self awarnes, menyeimbangkan jam istirahat, liburan, mencari dukungan dari orang sekitar serta membuat jadwal belajar.

\section{SIMPULAN}

Hasil uji analisis statistika menunjukkan ada perbedaan pemahaman 
pada guru antara sebelum diberikan materi dan sesudah diberikan materi. Dengan demikian maka dapat disimpulkan bahwa guru mampu memahami kegiatan pelatihan yag diberikan terkait permasalahan yang dialami oleh siswa yakni kejenuhan belajar daring selama masa pandemi. Guru mampu memahami karakteristik siswa yang mengalami kejenuhan dalam belajar dan tahu cara untuk mengatasi kejenuhan yang dialami oleh siswa.

Hasil penelitian ini menjelaskan bahwa kegiatan pelatihan yang diberikan bermanfaat karena guru mendapatkan suatu pengetahuan baru terkait strategi mengatasi kejenuhan belajar siswa.

Saran yang dapat diberikan adalah agar lebih banyak lagi metode serta kegiatan pelatihan serupa dalam bidang pendidikan agar peserta dalam hal ini guru maupun siswa lebih bisa memahami dan memanfaatkan produk atau modul secara tepat sesuai dengan kebutuhan.

\section{DAFTAR PUSTAKA}

Al-Shara, I. 2015. Learning and Teaching Between Enjoyment and Boredom As Realized By the Students: a Survey From the Educational Field. European Scientific Journal, 11(19): 1857-7881.

Arirahmanto, S. B. 2016. the Development of Burnout Reduction Application Based on Android for Smpn 3 Babat Students. Unesa, $6,2$.

Daschmann, E. C., Goetz, T., \& Stupnisky, R. H. 2011. Testing the predictors of boredom at school: Development and validation of the precursors to boredom scales. British Journal of Educational Psychology, 81(3):421-440. https://doi.org/10.1348/ooo709910X 526038

Fikri, M., Ananda, M. Z., Faizah, N., Rahmani, R., Elian, S. A., \& Suryanda, A.2021. KENDALA DALAM PEMBELAJARAN JARAK JAUH DI MASA PANDEMI COVID-19: SEBUAH KAJIAN KRITIS. 9(1): 145-148.
Gulo. 2008. Strategi Belajar Mengajar. Grasindo.

Handayani, L. 2020. Keuntungan, Kendala dan Solusi Pembelajaran Online Selama Pandemi Covid-19: Studi Ekploratif di SMPN 3 Bae Kudus Lina Handayani. Journal Industrial Engineering $\mathcal{E}$ Management Research, 1(2): 15-23.

Hui, S., \& Lin, S. H. 2010. Canonical Correlation Analysis on Life Stress and Learning Burnout Canonical Correlation Analysis on Life Stress and Learning Burnout of College Students in Taiwan Canonical Correlation Analysis on Life Stress and Learning Burnout. International Electronic Journal of Health Education, 13,145-155.

Lisman, Markuna, \& Wicaksono, H. 2020. Strategi Guru dalam Mengatasi Kejenuhan Belajar Siswa di MTs Al-Maarif Banyorang. Jurnal Al-Qiyam, 1(1): 54-69.

Magrur, R. Y., Siregar, N. R., \& Silondae, D. P.2020. Pengaruh Layanan Konseling Kelompok Terhadap Kejenuhan Belajar Siswa. Jurnal Ilmiah Bening: Belajar Bimbingan Dan Konseling, 4(1): 117-124. https://doi.org/10.36709/bening.v4i1.10496

MuhibbinSyah.2014. Psikologi Pendidikan dengan Pendekatan Baru. PT.Remaja Rosdakarya.

Muna,N. R.2013. Efektifitas Teknik Self Regulation Learning. 14(02): 57-78.

Nasution,Wahyudi N. 2017. Strategi Pembelajaran. Perdana Publishing.

Nurkholis Nurkholis.202o. Dampak Pandemi Novel- Corona Virus Disiase (Covid) 19 Terhadap Psikologi dan Pendidikan Serta Kebijakan Pemerintah. PGSD, 6(1): 39-49. https://doi.org/https://doi.org/10.32534/jps. v6i1.1035

Pawicara,R.,\&Conilie,M.2020.Analisis Pembelajaran Daring Terhadap Kejenuhan Belajar Mahasiswa Tadris Biologi Iain Jember di Tengah Pandemi Covid-19. ALVEOLI: Jurnal Pendidikan Biologi, 1(1):2938.

Purwanto, A., Pramono, R., Asbari, M., Santoso, P. B., Wijayanti, L. M., Choi, C. H., \& Putri, R. S. 2020. Studi Eksploratif Dampak Pandemi COVID-19 Terhadap Proses Pembelajaran Online di Sekolah Dasar. EduPsyCouns: Journal of Education, Psychology and Counseling, 2(1): 1-12. https://ummaspul.ejournal.id/Edupsycouns/article/view/397

Putria, H., Maula, L. H., \& Uswatun, D. A. 2020. Analisis Proses Pembelajaran dalam Jaringan (DARING) Masa Pandemi Covid19 Pada Guru Sekolah Dasar. Jurnal 
Basicedu, $\quad 4(4): \quad$ 861-870. https://doi.org/10.31004/basicedu.v4i4.460 Rimbarizki, R. 2017. Penerapan Pembelajaran Daring Kombinasi Dalam Meningkatkan Motivasi Belajar Peserta Didik Paket C Vokasi Di Pusat Kegiatan Belajar Masyarakat (Pkbm) Pioneer Karanganyar. J+Plus Unesa, 6(2): 1-12.

Rinawati, D., \& Darisman, E. K. 2020. Survei tingkat kejenuhan siswa SMK belajar di rumah pada mata pelajaran produk kreatif dan kewirausahaan selama masa pandemi covid-19. Journal of Science and Education, 1(1): 32-40.

Tze, V. M. C., Daniels, L. M., \& Klassen, R. M. 2016. Evaluating the Relationship Between Boredom and Academic Outcomes: A Meta-Analysis. Educational Psychology Review, 28(1):119-144. https://doi.org/10.1007/s10648-015-9301-y 